\title{
KERAGAMAN JENIS HAMA KUTU PUTIH PADA TANAMAN SINGKONG DI KOTA ENDE
}

\author{
Wifridus Sabinus B. Lena', Yustina M.S.W. Puu ${ }^{2}$ \\ Dosen Program StudiAgroteknologiFakultasPertanianUniversitas Flores \\ Jl. Sam Ratulangi-Paupire, Ende-Flores, NTT \\ yus_puu@yahoo.com
}

\begin{abstract}
This study aims to determine the type of white lice (Mealybug) pest associated with cassava plants (ManihotesculentaCrantz) in Ende Regency.

The observation variables used included the identification of the hamlet species found in the field and calculating the level of diversity, abundance, dominance, similarity / similarity and intensity of pest attacks.

The results showed that the diversity index for Nangapanda District was 1.052 (medium), abundance of 0.243 (low), and dominance index of 0.465 (moderate). Ende District diversity index 0.953 (low), abundance 0.348 (low), and dominance index 0.428 (moderate). Ende Selatan Subdistrict diversity index is 0.927 (low), abundance is 0.351 (low), and dominance index is 0.438 (moderate). In NdonaSubdistrict the diversity index is 0.683 (low), abundance is 0.358 (low), and dominance is 0.397 (moderate). For the similarity / similarity type index between Nangapanda sub-district and other sub-districts which is $85.71 \%$. Similarity / similarity between Ende District and three other Sub-districts, namely $85.71 \%, 100 \%$ and $100 \%$. The similarity between Ende Selatan District and the other three Sub-districts is $85.71 \%, 100 \%$ and $100 \%$. The similarity between NdonaSubdistrict and the other three Subdistricts is $85.71 \%, 100 \%$ and $100 \%$. While the intensity of pest damage in each Subdistrict was 47.7\%, in Ende District 32.5\%, South Ende 25\% and Ndona District 38.33\%.
\end{abstract}

Keywords: Mealybug, intensity, cassava.

\section{PENDAHULUAN}

Singkong merupakan salah satu tanaman pangan selain beras sebagai sumber karbohidrat dan merupakan makanan pokok hampir sebagian besar penduduk Indonesia. Keberlanjutan tanaman singkong di lapang sangat dipengaruhi oleh berbagai faktor baik biotik maupun abiotik. Produksi Nasional tanaman singkong pada kurun waktu lima tahun sejak 2011-2015 mengalami penurunan sebesar $0,06 \%$ per tahun.
Kabupaten Ende sebagai salah satu Kabupaten yang ada di wilayah Nusa Tenggara Timur dengan kondisi iklim yang sesuai untuk budidaya tanaman singkong dan memiliki salah satu kekhasan jenis singkong yang disebut dengan "Ubi Nuabosi". Berdasarkan hasil wawancara dengan petani di desa Ndetundora (2017) di lapangandidapatkan adanya serangan hama kutu putih (Mealybug sp).pada setiap pertanaman tanaman singkong di kota Ende 
dan menyebabkan penurunan kualitas umbi singkong yang dihasilkan.

Kutu putih singkong (Mealybug sp.) merupakan kelompok serangga dari Famili Pseudoccocidae dengan ciri seluruh tubuhnya dilapisi lilin yang berwarna putih (William and Granara de Willink, 1992). Hama ini mulai menyerang tanaman singkong pada umur 8 minggu setelah tanam (MST) sampai umur 16 MST dan biasanya berada di bawah permukaan daun dan berada di dekat pertulangan daun (Calatayud\& Le Ru, 2006).Spesies kutu putih yang diduga menyerang tanaman singkong di Indonesia yaitu Phenacoccus manihoti, Paracoccus marginatus, dan Ferrisia virgata (Chandra, 2008; Pramayudi dan Oktarina, 2008). Menurut Nasution (2012) bahwa spesies $F$. virgata dilaporkan ada di Indonesia sebelum tahun 1990-an, sedangkan $\quad P$. marginatusdiketahui keberadaannya pertama kali pada bulan Mei 2008 di pertanaman pepaya Kebun Bogor oleh tim IPM CRSP (Muniappan et al. 2008)

Serangan kutu putih atau mealybug pada tanaman ditandai dengan munculnya material tebal berwarna putih dan atau hitam pada permukaan daun atau apeks, yang merupakan campuran antara keberadaan serangga dewasa, ovisacs dan nimfa dari serangga tersebut dan menutupi organ inangnya dengan membuat lapisan yang menutupi organ terinfeksi tersebut sehingga inangnya mengalami gangguan fotosintesis dan pertumbuhan (Nurmasari, 2015). Kerusakan hama kutu putih terlihat secara nyata di lapangan, tetapi belum ada pengamatan khusus yang dilakukan oleh Dinas Pertanian Kabupaten Ende tentang jenis kutu putih serta intensitas kerusakan yang ditimbulkan pada tanaman singkong. Untuk itu, maka perlu dilakukan penelitian awal untuk mendapatkan jenis kutu putih yang ada pada pertanaman singkong di Kota Ende sebagai langkah dalam melakukan tindakan pengendalian yang tepat. Tujuan dari penelitian ini adalah untuk mengetahui keragaman jenis hama kutu putih Mealybug dan intensitas kerusakan yang ditimbulkan pada tanaman singkong di kota Ende.

\section{METODE PENELITIAN}

Penelitian ini dilaksanakan dari bulan Mei hingga Juli 2018 dengan lokasi penelitian diantaranya Kecamatan Ende, Kelurahan Ndorurea(Ndorurea I dan II), Kecamatan Ende, Desa Ndetundora I dan Ndetundora II, Kecamatan Ende Sealatan, Kelurahan Rukun Lima dan Kelurahan Tetandara, dan Kecamatan Ndona, Desa Nanganesa (Nanganesa I dan II) serta di Laboratorium Fakultas Pertanian Universitas Flores.

Penelitian ini adalah penelitian survei dengan pengamatan secara langsung pada kebun atau pekarangan tanaman singkong yang terdapat pada beberapa lokasi di Kabupaten Ende sebagai sentra pengahasil singkong yang ditetapkan berdasarkan keberadaan tanaman inang. Penentuan lokasi pengamatan ditentukanberdasarkan keberdaaan tanaman inang. Sedangkan untuk petak contoh ditentukan pada kebun atau pekarangan dengan luasan lahan $\pm 0,5$ ha. Pengambilan sampel pada setiap lokasi pengamatan dilakukan pada tanaman singkong secara acak sederhana. Jumlah tanaman inang yang diamati adalah $10 \%$ dari populasi yang ada di kebun/pekarangan. Sebelum pengambilan 


\section{Lena : Keragaman Jenis Hama Kutu Putih Pada Tanaman Singkong}

sampel kutu putih, terlebih dahulu mengukur ketinggian tempat dan ordinat dengan menggunakan GPS. Untuk pengamatan dilakukan melalui pengamatan langsung di tanaman singkong yang terserang kutu putih dengan cara mengambil jenis hama yang ditemukan dan dimasukkan ke dalam amplop untuk selanjutnya diidentifikasi.Pengamatan tingkat serangan dilakukan dengan menghitung jumlah tanaman yang terserang hama kutu putih dibagi dengan jumlah tanaman yang diamati. Variabel pengamatan yang akan digunakan dalam penelitian ini adalah sebagai berikut:

1. Keragaman jenis kutu putih

Keragaman jenis hama kutu putih yang berasosiasi dengan tanaman ubi kayu dilakukan dengan cara menghitung jumlah individu per spesies yang ditemukan dan dihitung indeks keragaman jenis menggunakan rumus Indeks Keragaman Shannon-Wiener: H' $=-\Sigma p i \ln$ pi $\rightarrow$ pi $=\frac{n i}{N}$

2. Kelimpahan populasi hama kutu putih Untuk kelimpahan jenis hama kutu putih yang berasosiasi dengan tanaman ubi kayudilakukan dengan menjumlahkan per individu masing-masing jenis kutu putih yang ditemukan: $\mathbf{R} \mathbf{1}=\frac{\mathbf{s}-\mathbf{1}}{\mathbf{L n} . \mathbf{N}}$

3. Kesamaan komunitas hama kutu putih di dua lokasi atau habitat yang berbeda.

Untuk Kesamaan komunitas dilakukan pada semua lokasi tempat penelitian berlangsung dalam melihat kesamaan jenis yang ada di lokasi yang berbeda dan dihitung indeks kesamaan komunitas menggunakan indeks Sorensen:

$$
\text { IS }=\frac{2 c}{A+B} \times 100 \%
$$

4. Dominasi jenis kutu putih

Untuk mengetahui dominasi jenis kutu putih yang ada di berbagai lokasi dilakukan dengan caramenjumlahkan dan membandingkan seluruh jenis yang di peroleh pada semua perlakuan serta ulangan dengan menggunakan rumus indeks dominasi: $\sum \frac{\mathbf{N i}(\mathbf{N i}-\mathbf{1})}{\mathbf{N}(\mathbf{N}-\mathbf{1})}$

5. Intensitas kerusakan

Intensitas kerusakan akibat serangan hama dapat diketahui dengan caramembandingkan banyaknya tanaman atau bagian tanaman yang terserang hama dari sampel yang diamati dengan banyaknya tanaman sampel yang diamati: $\sum \frac{\mathbf{n i} \times \mathbf{v i}}{\mathbf{Z} \times \mathbf{N}} \times \mathbf{1 0 0 \%}$

Data dianalisis menggunakan rumus yang digunakan sesuai variabel yang diamati.

\section{HASIL DAN PEMBAHASAN Jenis Hama Kutu Putih yang Ditemukan pada Tanaman Singkong}

Jenis hama kutu putih yang ditemukan pada tanaman singkong di empat Kecamatan yang dijadikan lokasi penelitian yakni sebanyak empat jenis kutu putih. Beberapa jenis tersebut adalah Phenacoccus manihoti, Paracoccus marginatus, Ferrisia virgata, dan Pseudococcus Jackbreadsleyi.

Phenacoccus manihoti mempunyai tubuh berbentuk oval agak pipih, berwarna merah mudah, dan mempunyai rambutrambut atau seta di sekeliling tubuhnya. Kemudian, bisanya tubuh dari hama jenis ini di selimuti oleh lapisan-lapisan lilin berwarna putih.Paracoccus marginatus berwarna kuning, tubuhnya berbentuk bulat 
agak lonjong. Dari hasil pengamatan menggunakan mikroskop ditemukan pula lapisan lilin berwarna putih yang menyelimuti tubuhnya dan memiliki seta atau rambut di sekeing tubuhnya. Ferrisia virgata memiliki tubuh oval agak lonjong, berwarna putih dan memiliki tanda berwarna hitam di belakang bagian atas dari tubuhnya. Hama ini tidak memiliki seta atau rambut di sekeliling tubuhnya, hanya saja $F$. virgata memiliki sepasang seta yang panjang yang ekor. Sama halnya dengan kutu putih jenis lainnya hama ini memiliki lapisan-lapisan lilin yang menyelimuti tubuhnya. Tanaman inang lain dari hama ini yakni tanaman hortikultura dan tanaman hias. PseudococcusJackbreadslyi memiliki rambut atau seta di sekeliling tubuh dan di belakang tubuh atau bagian belakan punggung, berwarna kecoklatan, dan dilapisi oleh lilin putih diseluruh bagian tubuhnya. Hama ini pun memiliki sepasang seta yang lebih panjang dari seta lain disekeliling tubuhnya yang menyerupai ekor (Gambar $1)$.

Keragaaman Jenis, kelimpahan jenis, dan

Dominansi jenis Hama Kutu Putihyang ditemukan pada tanaman Singkong.
Jenis kutu putih yang ditemukan di Kecamatan Nangapanda yakni tiga jenis diantaranya $P$. manihoti, $P$. marginatus, dan $F$. virgata, dengan indeks keragaman jenis sebesar 1,052, indeks kelimpahan jenissebesar 0,243 dan indeks dominansi sebesar 0,465(Tabel 1). Untuk kecamatan Ende ditemukan 4 jenis hama kutu putih yaitu $P$. manihoti, $P$. marginatus, $F$. virgata dan P.Jackbreadslyi dengan indeks keragaman jenis sebesar 0,953, indeks kelimpahan jenis sebesar 0,348 , dan indeks dominasi 0,428. Untuk kecamatan Ende Selatan ditemukan 4 jenis hama kutu putih yaitu $P$. manihoti, $P$. Keragaman jenis hama kutu putih pada semua lokasi pengamatan tergolong sedang sampai rendah. Hal ini didasarkan pada jenis hama kutu putih yang berkisar 3-4 jenis disetiap lokasi pengamatan. Hasil ini diperkuat oleh Odum (1998) bahwa Keanekaragaman jenis hama dipengaruhi oleh proporsi individu dari setiap jenisnya, karena dalam suatu komunitas walaupun terdiri dari berbagai jenis organisme tetapi penyebaran individunya tidak merata maka keanekaragamannya rendah (Odum, 1998).

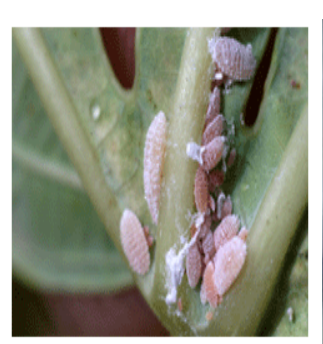

(a)

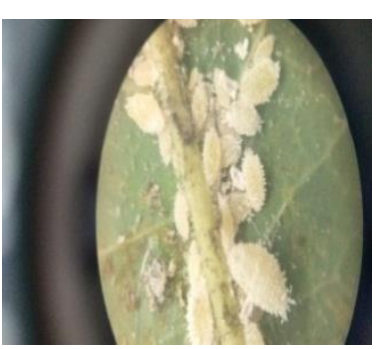

(b)

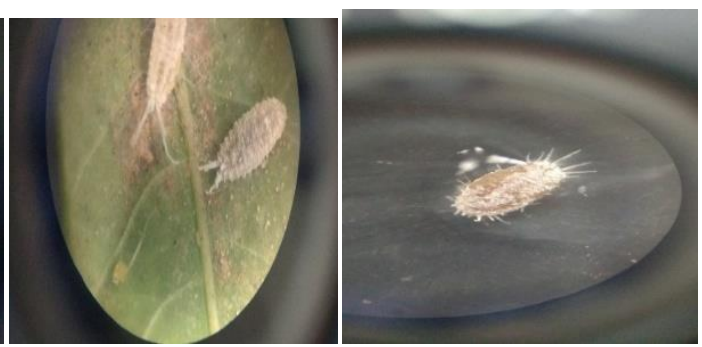

(c)

(d)
P. marginatus

F. virgataJackbreadslyi

Gambar 1. Jenis-jenis Kutu Putih(Mealybug) (Dokumen pribadi, 2018) 


\section{Lena : Keragaman Jenis Hama Kutu Putih Pada Tanaman Singkong}

Kelimpahan jenis tergolong rendah di semua lokasi pengamatan, karena dipengaruhi oleh faktor tersedianya makanan dimana tanaman inang yang tersedia hanyalah tanaman singkong (ubi kayu), pepaya dan pisang. Hal tersebut menandakan bahwa kelimpahan jenis hama kutu putih yang ditemukan sangat terbatas pada empat jenis saja, sesuai dengan tanaman inang yang ada. Menurut Susniahti, et al (2005) menyatakan bahwa salah satu pengahambat perkembangan hama yaitu faktor kompetisi antar hama itu sendiri dalam mempeoleh makanan dan tempat berlindung.

Marginatus, $\quad$ F. virgata dan P.Jackbreadslyi, dengan indeks keragaman jenis sebesar 0,927, indeks kelimpahan jenis sebesar 0,351, dan indeks dominasinya 0,428. Untuk kecamatan Ende Selatan ditemukan 4 jenis hama kutu putih yaitu $P$. manihoti, $P$. marginatus, $F$. virgata dan P.Jackbreadslyi, dengan indeks keragaman jenis sebesar 0,927, indeks kelimpahan jenis sebesar 0,351 kriteria rendah, dan indeks dominasi sebesar 0,428 (Tabel 1). Untuk kecamatan Ndona indeks ditemukan 4 jenis hama kutu putih yaitu $P$. manihoti, $P$. marginatus, F. virgata dan P.Jackbreadslyi, dengan indeks keragaman jenis sebesar 0,683, indeks kelimpahan jenis sebesar 0,358, dan indeks dominansi sebesar 0,397 (Tabel 1).

Keragaman jenis hama kutu putih pada semua lokasi pengamatan tergolong sedang sampai rendah. Hal ini didasarkan pada jenis hama kutu putih yang berkisar 3-4 jenis disetiap lokasi pengamatan. Hasil ini diperkuat oleh Odum (1998) bahwa Keanekaragaman jenis hama dipengaruhi oleh proporsi individu dari setiap jenisnya, karena dalam suatu komunitas walaupun terdiri dari berbagai jenis organisme tetapi penyebaran individunya tidak merata maka keanekaragamannya rendah (Odum, 1998). Kelimpahan jenis tergolong rendah di semua lokasi pengamatan, karena dipengaruhi oleh faktor tersedianya makanan dimana tanaman inang yang tersedia hanyalah tanaman singkong (ubi kayu), pepaya dan pisang. Hal tersebut menandakan bahwa kelimpahan jenis hama kutu putih yang ditemukan sangat terbatas pada empat jenis saja, sesuai dengan tanaman inang yang ada. Menurut Susniahti, et al (2005) menyatakan bahwa salah satu pengahambat perkembangan hama yaitu faktor kompetisi antar hama itu sendiri dalam mempeoleh makanan dan tempat berlindung.

Sedangkan untuk indeks dominasi di Kecamatan Nangapanda serta tiga Kecamatan lainnya tergolong sedang. Dominasi suatu jenis hama pada suatu wilayah dipengaruhi oleh ketinggian tempat dan kondisi cuaca. Dari hasil pengamatan yang dilakukan, ketinggian tempat pada empat wilayah Kecamatan yang dijadikan lokasi penelitian bervariasi, baik di daerah dataran rendah maupun dataran sedang. Kondisi cuaca yang baik pun mendukung tinggi rendahnya dominasi suatu jenis hama pada suatu wilayah. Jika cuaca panas maka tidak menutup kemungkinan perkembangan serta dominasi suatu jenis hama pada suatu wilayah akan tinggi. Hal tersebut juga diungkapkan oleh Wardani (2015) bahwa suhu yang lebih panas dengan kelembapan udara yang rendah merupakan kondisi yang lebih sesuai bagi perkembangan hama kutu putih. Begitupun sebaliknya, hujan sangat 
berperan penting sebagai pengendali alami dalam menekan perkembangan populasi hama, serta dominasi suatu jenis hama pada suatu wilayah. Menurut Herren dan
Hennessey (1983) menyatakan bahwa hujan merupakan faktor penentu dalam dinamika populasi hama kutu putih di lapangan.

Tabel 1. Indeks keragaman jenis, kelimpahan jenis dan dominansi jenis Hama Kutu putih yang ditemukan pada tanaman singkong di beberepa lokasi

\begin{tabular}{|c|c|c|c|c|c|c|c|c|}
\hline \multirow{2}{*}{ Kecamatan } & \multicolumn{4}{|c|}{ Keragaman Jenis } & \multirow{2}{*}{$\begin{array}{c}\text { Kelimpahan Populasi } \\
\text { (ekor) }\end{array}$} & \multirow{2}{*}{$\mathrm{H}^{\prime}$} & \multirow{2}{*}{ R1 } & \multirow{2}{*}{ D } \\
\hline & Kelas & Ordo & Family & Spesies & & & & \\
\hline \multirow{3}{*}{ Nangapanda } & Insekta & Hemiptera & Pseudococcidae & Phenacoccus manihoti & 905 & 1,052 & 0,243 & 0,465 \\
\hline & Insekta & Hemiptera & Pseudococcidae & Paracoccus marginatus & 1065 & \multirow[t]{2}{*}{ (Sedang) } & (Rendah) & (Sedang) \\
\hline & Insekta & Hemiptera & Pseudococcidae & Ferrisia virgata & 1783 & & & \\
\hline \multirow{4}{*}{ Ende } & Insekta & Hemiptera & Pseudococcidae & Phenacoccus manihoti & 3155 & 0,953 & 0,3548 & 0,428 \\
\hline & Insekta & Hemiptera & Pseudococcidae & Paracoccus marginatus & 1541 & \multirow[t]{3}{*}{ (Rendah) } & (Rendah) & \multirow[t]{3}{*}{ (Sedang) } \\
\hline & Insekta & Hemiptera & Pseudococcidae & Ferrisia virgata & 791 & & & \\
\hline & Insekta & Hemiptera & Pseudococcidae & Jackbreadslyi & 1 & & & \\
\hline \multirow{4}{*}{ Ende Selatan } & Insekta & Hemiptera & Pseudococcidae & Phenacoccus manihoti & 2722 & 0,927 & 0,351 & 0,438 \\
\hline & Insekta & Hemiptera & Pseudococcidae & Paracoccus marginatus & 1950 & \multirow[t]{3}{*}{ (Rendah) } & (Rendah) & \multirow[t]{3}{*}{ ) (Sedang) } \\
\hline & Insekta & Hemiptera & Pseudococcidae & Ferrisia virgata & 356 & & & \\
\hline & Insekta & Hemiptera & Pseudococcidae & Jackbreadslyi & 45 & & & \\
\hline \multirow{4}{*}{ Ndona } & Insekta & Hemiptera & Pseudococcidae & Phenacoccus manihoti & 1985 & 0,683 & 0,358 & 0,397 \\
\hline & Insekta & Hemiptera & Pseudococcidae & Paracoccus marginatus & 1809 & \multicolumn{3}{|c|}{ (Rendah)(Rendah) (Sedang) } \\
\hline & Insekta & Hemiptera & Pseudococcidae & Ferrisia virgata & 500 & & & \\
\hline & Insekta & Hemiptera & Pseudococcidae & Jackbreadslyi & 35 & & & \\
\hline
\end{tabular}

Kesamaan Jenis Hama kutu Putih di Empat Kecamatan

Indeks Similaritas/Kesamaan jenis kutu putih Mealybug pada tanaman singkong di empat lokasi Kecamatan menunjukkan bahwa kesamaan kutu putih yang antar kecamatan adalah mendekati nilai hampir sama, dengan persentase indeks yang tinggi mencapai 85,71 - $100 \%$. Kesamaan jenis hama kutu putih dilihat dengan membandingkan jumlah kutu putih antar dua lokasi survei (Tabel 2.).

Tabel 2. Similaritas/Kesamaan Jenis Hama Kutu Putih di Empat Kecamatan.

\begin{tabular}{lcccc}
\hline Kecamatan & $\begin{array}{c}\text { Nangapanda } \\
\mathbf{\%}\end{array}$ & $\begin{array}{c}\text { Ende } \\
\mathbf{\%}\end{array}$ & $\begin{array}{c}\text { Ende Selatan } \\
\mathbf{\%}\end{array}$ & $\begin{array}{c}\text { Ndona } \\
\mathbf{\%}\end{array}$ \\
\hline Nangapanda & & $85,71 \%$ & $85,71 \%$ & $85,71 \%$ \\
Ende & $85,71 \%$ & & $100 \%$ & $100 \%$ \\
Ende Selatan & $85,71 \%$ & $100 \%$ & & $100 \%$ \\
Ndona & $85,71 \%$ & $100 \%$ & $100 \%$ & \\
\hline
\end{tabular}


Analisis similaritas atau kesamaan jenis hama kutu putih di empat wilayah Kecamatan tersebut tergolong cukup tinggi yakni 85 hingga 100\%. Hal ini disebabkan karena ditemukannya jenis hama kutu putih yang sama di empat Kecamatan yang menjadi lokasi penelitian. Berbeda dengan Kecamatan Nangapanda, dari hasil analisis indeks similaritas/kesamaan jenis kutu putih, wilayah ini hanya mendapatkan $85,71 \%$. Hasil ini diperoleh karena diwilayah ini hanya ditemukan tiga jenis hama kutu putih saja. Sedangkan wilayah lainnya ditemukan empat jenis hama kutu putih yang sama hanya berbeda jumlah populasi tiap individunya. Tingginya kesamaan jenis hama kutu putih diwilayah tersebut juga dipengaruhi oleh adanya tanaman inang yang sama atau sejenis. Menurut Magurran (1988) dalam Kartono (2006) mengatakan bahwa tingginya kesamaan jenis dipengaruhi oleh kesamaan komunitas baik itu tanaman inang maupun hal lainnya yang identik.

\section{Intesitas Serangan Jenis Hama Kutu Putih di Empat Kecamatan.}

Intensitas serangan hama kutu putih di Kecamatan Nangapanda sebesar 47,7\%. Di Kecamatan Ende sebesar 32,5\%, Kecamatan Ende Selatan sebesar 25\%, dan di Kecamatan Ndona sebesar 38,33\% (Tabel 3.)

Tabel 3. Intensitas Serangan Jenis Hama Kutu Putih di Empat Kecamatan (\%).

\begin{tabular}{llc}
\hline No & \multicolumn{1}{c}{ Kecamatan } & IntensitasSerangan (\%) \\
\hline 1 & Nangapanda & 47,7 \\
2 & Ende & 32,5 \\
3 & Ende Selatan & 25 \\
4 & Ndona & 38,33 \\
\hline
\end{tabular}

Intensitas serangan jenis hama kutu putih pada empat wilayah Kecamatan tersebut dapat digolongkan dalam serangan atau kerusakan sedang mulai dari $25 \%$ 47,7\%. Dari hasil analsis yang dilakukan, intensitas serangan hama yang terjadi di wilayah Kecamatan Nangapanda lebih tinggi dibandingkan dengan tiga wilayah Kecamatan lainnya. Hal ini disebabkan oleh jumlah populasi jenis hama kutu putih per individu yang ditemukan sangat banyak atau melimpah. Dari hasil penelitian-penelitian lain juga mengatakan bahwa, tinggi rendahnya intensitas serangan suatu jenis hama pada suatu wilayah disebabkan oleh banyak tidaknya populasi per individu dari jenis hama yang ditemukan, serta tersedianya tanaman inang yang disukai oleh jenis hama tersebut. Hal yang sama juga diungkapkan oleh Manwan (1977), yang mengatakan bahwa tanaman inang juga memegang peranan penting dalam mengatur tinggi rendahnya populasi suatu jenis hama pada suatu wilayah.

\section{SIMPULAN}

Berdasarkan hasil penelitian yang dilakukan dapat disimpulkan bahwa:

1. Terdapat empat jenis hama kutu putih (Mealybug) yang menyerang tanaman singkong di Kabupate Ende, diantaranya;Phenacoccus 
manihoti, Paracoccus marginatus, Ferrisia virgata, dan Pseudococcus Jackbreadsleyi.

2. Keragaman dan kelimpahan jenis hama kutu putih yang ditemukan pada tanaman singkong di empat Kecamatanyakni Kecamatan Nangapanda indeks keragaman 1,052(sedang) dan kelimpahan 0,243(rendah).Kecamatan Ende, indeks keragaman 0,953(rendah) dan kelimpahan $\quad 0,348$ (rendah). Kecamatan Ende Selatan indeks keragaman $\quad 0,927$ (rendah) dan kelimpahan 0,351(rendah). Untuk Kecamatan Ndona indeks keragaman 0,683 (rendah) dan kelimpahan 0,358 (rendah).

3. Tingkat atau intensitas kerusakan yang disebabkan oleh hama kutu putih di empat Kecamatan tegolong sedang yakni Kecamatan Nangapanda 47,7\%, Kecamatan Ende $32,5 \%$, Kecamatan Ende Selatan 25\%, dan Kecamatan Ndona $38,33 \%$.

4. Jenis hama yang paling dominan yang ditemukan pada empat Kecamatan di Kabupaten Ende yakniPhenacoccus manihoti, Paracoccus marginatus, dan Ferrisia virgata serta hasil analisis dominasinya yakni di Kecamatan Nangapanda indeks dominasinya 0,465(rendah), Kecamatan Ende 0,428(sedang), Kecamatan Ende Selatan 0,438(sedang), dan Kecamatan Ndona indeks dominasinya sebesar 0,397 (sedang).

\section{UCAPAN TERIMA KASIH}

Pada kesempatan ini penulis ingin mengucapkan terima kasih kepada semua pihak yang telah membantu dengan caranya masing-masing dalam melengkapi tulisan ini.

\section{DAFTAR PUSTAKA}

Chandra, David. 2008. Inventarisasi Hama dan Penyakit pada Pertanaman Jarak Pagar (Jatropha curas Linn). Institut Pertanian Bogor.

Catalayud, P.A and B. Le Ru. 2006. Cassava-Mealybug Interactions. Institut de Reserche Pourle Development,Paris.https://www.rese archgate.net/publication/274509885_ Cassava-Mealybug_Interactions

Herren HR, Hennessey RN. 1983. Biological control and host plant resistance to control the cassava mealybug and green mite in Africa: Prosedings of an internasonal workshop. Ibadan, Niigeria: IITA. $154 \mathrm{p}$.

Kartono, Agus P. 2006. Diktat Kuliah Ekologi Kuantitatif. Departemen Konservasi Sumberdaya Hutan Dan Ekowisata. Tidak diterbitkan.

Manwan, I. 1977. Status Pengolahan Hama Tanaman Padi di Indonesia. Himpunan Makalah Simposium I Maros, 26-29 September 1997. Pusat dan Penelitian Pengembangan Tanaman Pangan Bogor.

Muniappan R, Shepard BM, Watson GW, Carner GR, Rauf A, Sartiami D, Hidayat P, AfunJVK, Goergen G, 


\section{Lena : Keragaman Jenis Hama Kutu Putih Pada Tanaman Singkong}

Rahman AKMZ. 2011. New records of invasive insects (Hemiptera: Sternorrhyncha) in Southern Asia and West Africa. Journal of Agricultural and Urban Entomology26:167-174. doi: https://doi.org/10.3954/1523-547526.4.167.

Nasution AP. 2012. Kelimpahan Arthropoda Predator Permukaan Tanah Pada Tiga

Ekosistem Pertanaman. [skripsi]. Bogor (ID): Institut Pertanian Bogor.

Nurmasari F. 2015. Keanekaragaman Kutu Putih Dan Musuh AlamiPada Tanaman Singkong (Manihot esculenta Crantz). [Tesis] (ID): Fakultas Matematika Dan Ilmu Pengetahuan Alam Universitas Jember
Odum EP. 1998. Dasar-dasar Ekologi. Edsi Ketiga. Gajah Mada University Press, Yogyakarta

Pramayudi, N. \& H. Oktarina. 2012. Biologi Hama Kutu Putih Pepaya (Paracoccus marginatus) pada Tanaman Pepaya. J. Floratek. 7: 32 44.

Susniahti, N., H, Sumeno dan Sudrajat. 2005. Bahan Ajar Ilmu Hama Tumbuhan. Universitas Padjajaran Bandung, 81 hal.

Wardani N. 2015. Kutu putih ubi kayu Phenacoccus manihoti MatileFerrero (Hemiptera Pseudococcidae), hama infasif baru di Indonesia [Disertasi]. Institut Pertanian Bogor. Bogor.

Williams DJ, Granara de Willink MC. 1992 Mealybugs of Central and South America. Wallingford, Oxon, United Kingdom: CAB International. 